\title{
The Role of Metal Dissolution in the Process of Chloride Stress Corrosion Cracking of Austenitic Stainless Steels*
}

\author{
By Hideya OKADA, ${ }^{* *}$ Yuzo HOSOI** and Seizaburo ABE**
}

\section{Synopsis}

The metal dissolution and the change in couple current (flowing between non-stressed and stressed specimens) have been measured in the process of stress corrosion cracking of austenitic stainless steels in the $\mathrm{MgCl}_{2}$ solution boiling at $143^{\circ} \mathrm{C}$. The results obtained are as follows:

(1) The metal dissolution occurs when the material is stressed beyond yield stress, (2) the metals dissolved during stress corrosion cracking are $\mathrm{Fe}$ and $\mathrm{Ni}$, whereas the dissolution of $\mathrm{Cr}$ is not detected, (3) it is found that the increase in the metal dissolution and the couple current is closely related to the propagation of cracks, (4) a non-sensitive material to stress corrosion cracking does not show any metal dissolution and flowing of the couple current, (5) cracks initiate at slip steps where fresh surfaces are exposed by plastic deformation, and (G) the propagation of cracks is stopped by the addition of a small amount of $\mathrm{NaNO}_{3}$ in the test solution and by the cathodic polarization.

From these experimental facts, the process of stress corrosion cracking of austenitic stainless steel in the $\mathrm{MgCl}_{2}$ solution can be considered as follows: At the beginning, the fresh surface exposed by slip is preferentially attacked by a corrosive environment and a groove is formed by the metal dissolution at this area, resulting in the crack initiation. At the crack tip, slip accompanied by the metal dissolution occurs again; thus the crack propagates by a cooperative action of the slip and the metal dissolution and finally the material is fractured.

\section{Introduction}

Numerous studies have been done on the stress corrosion cracking mechanism of austenitic stainless steels. The discussions involved are focused on either the corrosion accelerated by the stress, ${ }^{1,2)}$ the effect of stacking fault energy on the dislocation distribution, ${ }^{3-5)}$ the role of the surface film, ${ }^{6,7}$ the dominant effect of hydrogen ${ }^{8,9,15)}$ or the presence of critical potentials for stress corrosion cracking. ${ }^{10)}$ In spite of those enormous studies, it is hard to say that the cracking mechanism is well understood. One of the most ambiguous points in the previous works is that they are lacking in the quantitative analysis of dissolved metals during stress corrosion cracking.

In this study, the metal dissolution was quantitatively determined by the atomic absorption spectro- photometry. The minimum volume of the corrosive testing solution and the maximum specimen size made it possible to measure the amount of dissolved metals quantitatively during stress corrosion cracking.

The couple current flowing between the stressed and the unstressed specimens and the specimen elongation during test were measured in order to monitor the metal dissolution and the crack propagation. The crack growth was also examined microscopically in connection with the metal dissolution.

\section{Experimental}

\section{Specimens}

The chemical compositions of the specimens are listed in Table 1. AISI type 304 is commercial alloy. The other specimens are a highly pure Fe-20Cr$20 \mathrm{Ni}$ alloy and the similar alloys with the addition of $\mathrm{P}, \mathrm{N}$ or Mo. They were vacuum melted by a high frequency induction furnace. The specimen size is shown in Fig. 1. The specimens were enclosed in evacuated quartz tubes and were solution-treated at $1000^{\circ} \mathrm{C}$ for $60 \mathrm{~min}$, and subsequently quenched into water. They were polished with \#320 emery paper and rinsed with acetone and distilled water just before each test.

\section{Couple Current}

Figure 2 shows the schematic diagram of apparatus for the measurement of the couple current. The

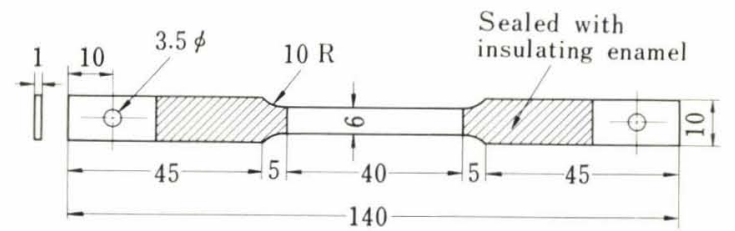

Fig. 1. Geometry of specimen

Table 1. Chemical compositions (wt \%) and proof stress $\left(\mathrm{kg} / \mathrm{mm}^{2}\right)$ of materials

\begin{tabular}{|c|c|c|c|c|c|c|c|c|c|c|}
\hline & $\mathrm{C}$ & $\mathrm{Si}$ & $\mathrm{Mn}$ & $\mathrm{P}$ & $\mathrm{S}$ & $\mathrm{Cr}$ & $\mathrm{Ni}$ & Mo & $\mathrm{N}$ & $\sigma_{0.2}$ \\
\hline 304 & 0.076 & 0.85 & 1.15 & 0.020 & 0.012 & 18.35 & 9.2 & 一 & 0.0250 & 22.0 \\
\hline $20 \mathrm{Cr}-20 \mathrm{Ni}$ & 0.014 & 0.02 & 0.01 & 0.003 & 0.008 & 19.16 & 19.9 & - & 0.0037 & 11.5 \\
\hline $20 \mathrm{Cr}-20 \mathrm{Ni}-0.03 \mathrm{P}$ & 0.012 & 0.02 & 0.01 & 0.034 & 0.007 & 19.78 & 20.6 & - & 0.0072 & 11.5 \\
\hline $20 \mathrm{Cr}-20 \mathrm{Ni}-0.08 \mathrm{P}$ & 0.012 & 0.02 & 0.01 & 0.076 & 0.007 & 19.14 & 20.0 & - & 0.0057 & 11.8 \\
\hline $20 \mathrm{Cr}-20 \mathrm{Ni}-0.32 \mathrm{P}$ & 0.017 & 0.02 & 0.01 & 0.317 & 0.008 & 19.50 & 20.3 & - & 0.0046 & 12.4 \\
\hline $20 \mathrm{Cr}-20 \mathrm{Ni}-1 \mathrm{Mo}$ & 0.049 & 0.15 & 0.01 & 0.003 & 0.007 & 19.23 & 19.41 & 0.98 & 0.0037 & 15.0 \\
\hline
\end{tabular}

* Received May 24, 1974.

** Fundamental Research Labs., Nippon Steel Corp., Ida, Kawasaki 211. 
couple current flowing between the stressed and the unstressed specimens with the same heat and surface treatments was examined by a zero resistance ammeter, ${ }^{*}$ and recorded continuously by an automatic recorder. Although some measurable current was observed at the moment when both of the specimens were immersed into the corrosive solution without stress, it reached almost zero value after 5 to $10 \mathrm{~min}$. After recognizing zero couple current, a constant stress was applied on one of the specimens. The accuracy of the current measurement was $\pm 1 \mu \mathrm{A}$.

\section{Dissolved Metal}

The corrosive solution for analysis was taken from the same cell as shown in Fig. 2 and the amount of dissolved metals were determined during and after stress corrosion cracking. The used corrosive medium was the boiling $\mathrm{MgCl}_{2}$ solution (b.p. $143^{\circ} \mathrm{C}$ ) prepared from guaranteed grade $\mathrm{MgCl}_{2}$.

About $60 \mathrm{~g}$ of the solution was taken from the test solution (132 g) and it was weighed exactly for the analysis. After diluting the solution to $100 \mathrm{ml}$ with the distilled water, $\mathrm{Fe}, \mathrm{Cr}$ and $\mathrm{Ni}$ contents were analyzed by the standard addition method of the atomic absorption spectrophotometry as shown in Fig. 3. The corrosive solution contained the following impurities: Fe by $0.10 \pm 0.03 \mathrm{mg}, \mathrm{Cr}$ by $0.07 \pm 0.03 \mathrm{mg}$ and $\mathrm{Ni}$ by $0.07 \pm 0.03 \mathrm{mg}$ in $100 \mathrm{~g}$, and these amounts of impurities were subtracted from the determined amounts of Fe, $\mathrm{Cr}$ and $\mathrm{Ni}$.

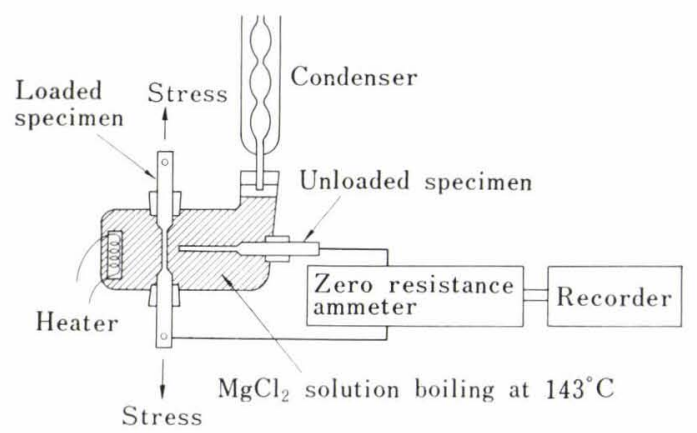

Fig. 2. Schematic diagram of apparatus for couple current measurement in stress corrosion cracking of austenitic stainless steel

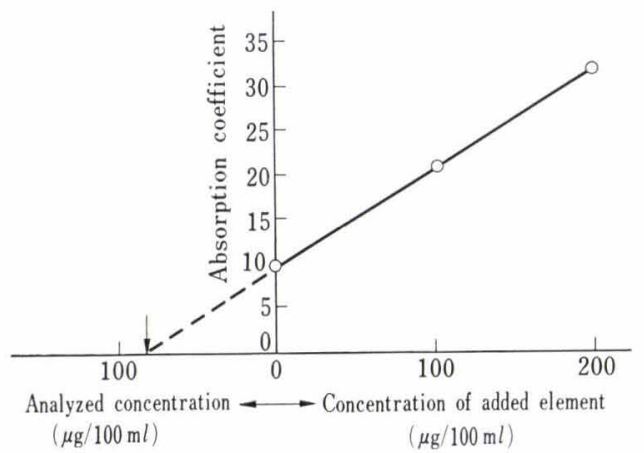

Fig. 3. Determination of dissolved metal content by standard addition technique with atomic absorption spectrophotometry

\section{Elongation}

In order to observe the progression of the stress corrosion cracking, the elongation of the specimen under a constant load was continuously measured by a differential transformer and a preamplifier. The elongation was measured with the accuracy of $\pm 0.17 \mu \mathrm{m}$.

\section{Experimental Results}

\section{Susceptibility to Stress Corrosion Cracking (SCC)}

The fracture times of the materials tested in the $\mathrm{MgCl}_{2}$ solution boiling at $143^{\circ} \mathrm{C}$ under the stress of $30 \mathrm{~kg} / \mathrm{mm}^{2}$ are summarized in Table 2. The most susceptible alloy, Type 304, showed the shortest fracture time of 40 to $60 \mathrm{~min}$. The highly pure Fe-20Cr$20 \mathrm{Ni}$ alloy did not fracture even after $330 \mathrm{hr}$, but the addition of small amount of phosphorus, nitrogen or molybdenum to the alloy caused remarkable increases of the SCC susceptibility.

\section{Relation between Couple Current and SCC Susceptibility}

The couple current was observed only when the applied stress was large enough to induce the plastic strain. Figure 4 shows both the typical couple cur-

Table 2. Susceptibility to stresss corrosion cracking of austenitic stainless steels

\begin{tabular}{l|c}
\hline \multicolumn{1}{|c|}{ Alloy } & $\begin{array}{c}\text { Time to fracture (hr) in } \mathrm{MgCl}_{2} \text { boiling } \\
\text { at } 143^{\circ} \mathrm{C}\end{array}$ \\
\hline 304 & $0.7 \sim 1.1$ \\
$20 \mathrm{Cr}-20 \mathrm{Ni}$ & $>330$ \\
$20 \mathrm{Cr}-20 \mathrm{Ni}-0.03 \mathrm{P}$ & 5.3 \\
$20 \mathrm{Cr}-20 \mathrm{Ni}-0.08 \mathrm{P}$ & 4.8 \\
$20 \mathrm{Cr}-20 \mathrm{Ni}-0.32 \mathrm{P}$ & 3.1 \\
$20 \mathrm{Cr}-20 \mathrm{Ni}-0.23 \mathrm{~N}$ & 23.2 \\
$20 \mathrm{Cr}-20 \mathrm{Ni}-1 \mathrm{Mo}$ & 2.4 \\
\hline
\end{tabular}

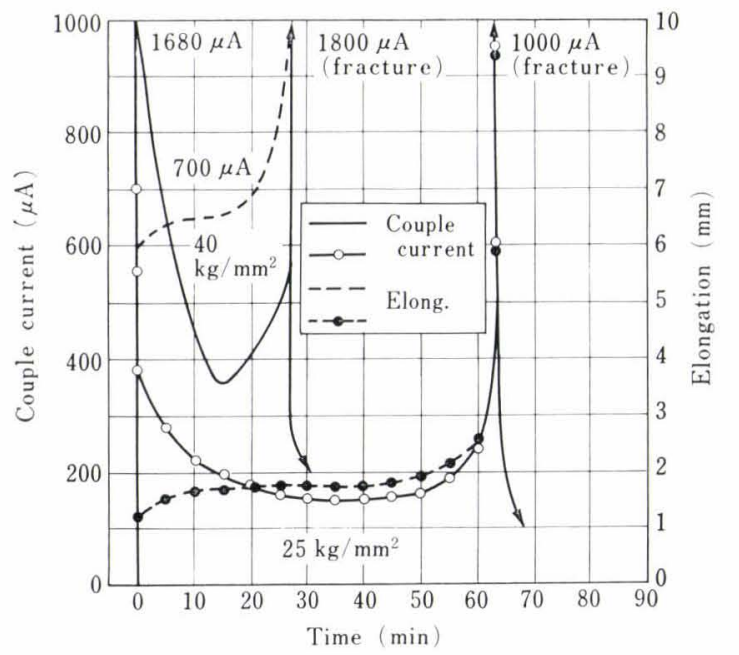

Fig. 4. Change in couple current and elongation with lapse of time in stress corrosion cracking of 304 stainless steel in $\mathrm{MgCl}_{2}$ boiling at $143^{\circ} \mathrm{C}$

\footnotetext{
* A newly designed ammeter which has zero resistance by a computed amplifier.
} 
rent-time and the elongation-time curves of Type 304 at two different stress levels.

In the case of an applied stress of $25 \mathrm{~kg} / \mathrm{mm}^{2}$, the initial current rise due to stress application was about $700 \mu \mathrm{A}$, but it decreased to about $400 \mu \mathrm{A}$ in a very short time. The current continued to decrease until

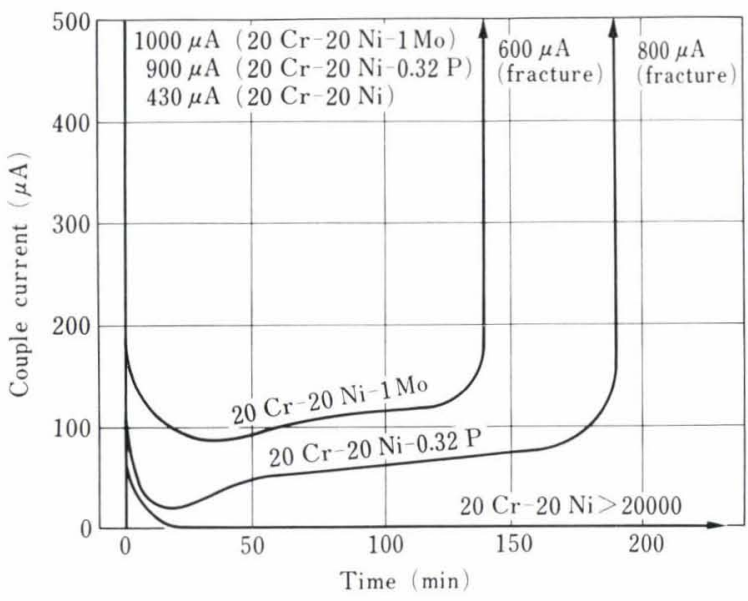

Fig. 5. Change in couple current with lapse of time in stress corrosion cracking of $20 \mathrm{Cr}-20 \mathrm{Ni}$ alloy steels in $\mathrm{MgCl}_{2}$ boiling at $143^{\circ} \mathrm{C}$

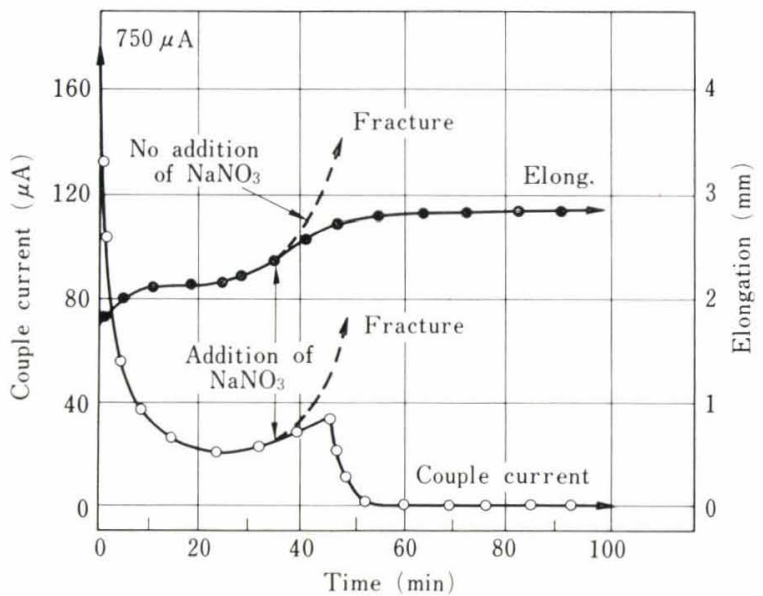

Fig. 6. Effect of $\mathrm{NaNO}_{3}$ addition on couple current and elongation in stress corrosion cracking of 304 stain less steel in $\mathrm{MgCl}_{2}$ boiling at $143^{\circ} \mathrm{C}$.

Applied stress: $\quad 30 \mathrm{~kg} / \mathrm{mm}^{2}, \mathrm{NaNO}_{3}$ added: $3 \%$

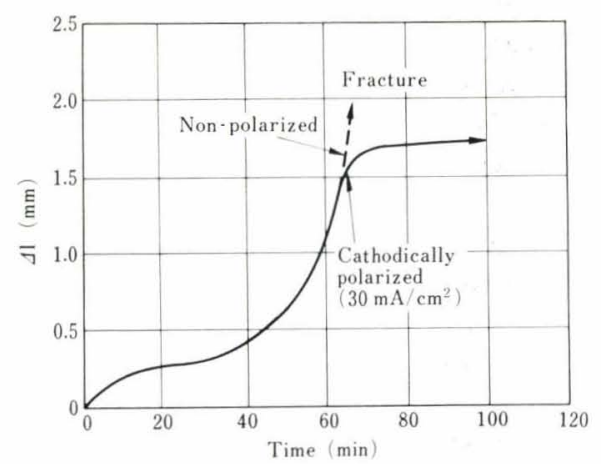

Fig. 7. Effect of cathodic polarization on the fracture behavior of 304 stainless steel in $\mathrm{MgCl}_{2}$ boiling at $143^{\circ} \mathrm{C}$

Applied stress: $\quad 30 \mathrm{~kg} / \mathrm{mm}^{2}, \Delta 1$ is the difference between initial length and elongated length it began to increase because of the progression of SCC. It reached approximately about $1000 \mu \mathrm{A}$ when the specimen was finally fractured, but the current decreased instantly after the fracture to less than $100 \mu \mathrm{A}$ and then to zero. The current was always observed to flow from the unstressed specimens to the stressed one. Therefore the stressed specimens were always more active than the unstressed ones. As it can be seen in Fig. 4, the elongation-time curves correspond closely to the couple current-time curves except for the period in which the elongation rate and the current are small. Figure 5 shows the couple currenttime curves of three alloys which have different SCC susceptibilities.

The susceptible alloys which contained phosphorus or molybdenum showed couple currents of 50 to $100 \mu \mathrm{A}$ from the instance of straining to the start of the rapid SCC. On the contrary, the non-susceptible alloy exhibited negligibly small currents except in the initial stage when the specimen was instantly strained. The zero couple current suggests that there is no major difference in the electrode behavior between the stressed and the unstressed specimens.

It was reported that the addition of inhibitors suppressed $\mathrm{SCC}$ in the $\mathrm{MgCl}_{2}$ solution. ${ }^{10)}$ Figure 6 demonstrates the effect of $\mathrm{NaNO}_{3}$ addition on the couple current and the elongation at the final stage of SCC where the cracks propagate very rapidly without $\mathrm{NaNO}_{3}$ addition. The addition of $3 \% \mathrm{NaNO}_{3}$ decreased the couple current to zero and finally stopped the elongation. The effect of $\mathrm{NaNO}_{3}$ will be discussed later.

The crack propagation was also suppressed by the cathodic polarization. Figure 7 clearly shows that the crack propagation is completely stopped by the application of cathodic current at the final stage of SCC.

\section{Metal Dissolution during SCC}

The metal dissolution was negligible when the unstressed specimens were exposed to the $\mathrm{MgCl}_{2}$ solution boiling at $143^{\circ} \mathrm{C}$ for the same period as the stressed specimens were fractured. The dissolution of both $\mathrm{Fe}$ and $\mathrm{Ni}$ was observed in the stressed susceptible alloys. However $\mathrm{Cr}$ was not detected to be dissolved. Figure 8 shows the effect of the applied stress on the amount of the dissolved metals. The ratio of

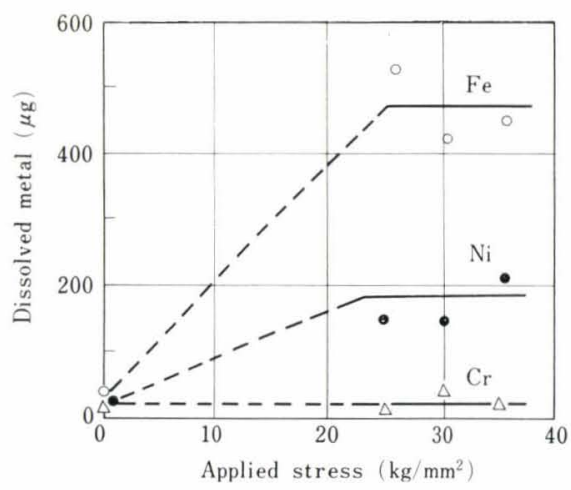

Fig. 8. Effect of applied stress on dissolution of metals in $20 \mathrm{Cr}-20 \mathrm{Ni}-0.034 \mathrm{P}$ steel in $\mathrm{MgCl}_{2}$ boiling at $143^{\circ} \mathrm{C}$ 


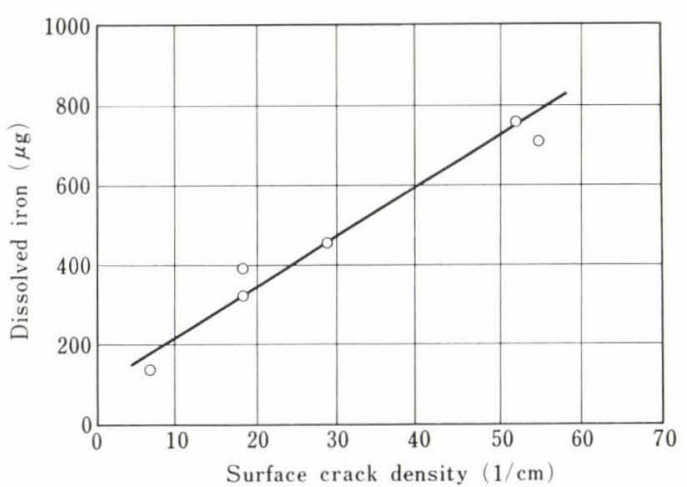

Fig. 9. Relation between amount of dissolved iron and surface crack density in $20 \mathrm{Cr}-20 \mathrm{Ni}-0.034 \mathrm{P}$ steel in $\mathrm{MgCl}_{2}$ boiling at $143^{\circ} \mathrm{C}$

Applied stress: $35 \mathrm{~kg} / \mathrm{mm}^{2}$

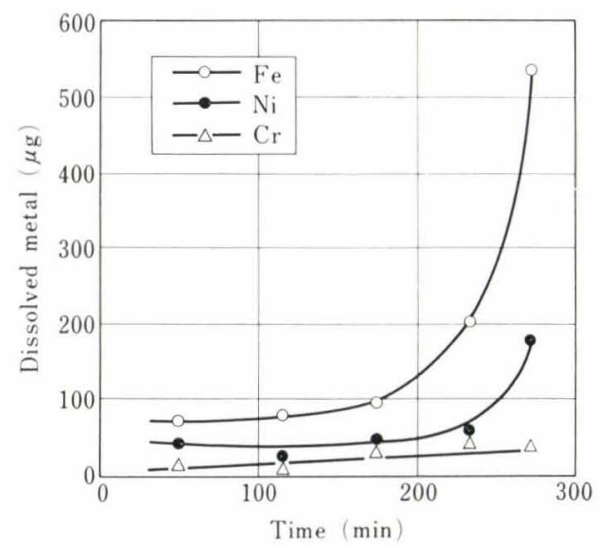

Fig. 10. Change in amount of dissolved metals with lapse of time in stress corrosion cracking of $20 \mathrm{Cr}-20 \mathrm{Ni}-$ $0.076 \mathrm{P}$ steel in $\mathrm{MgCl}_{2}$ boiling at $143^{\circ} \mathrm{C}$

Applied stress: $35 \mathrm{~kg} / \mathrm{mm}^{2}$

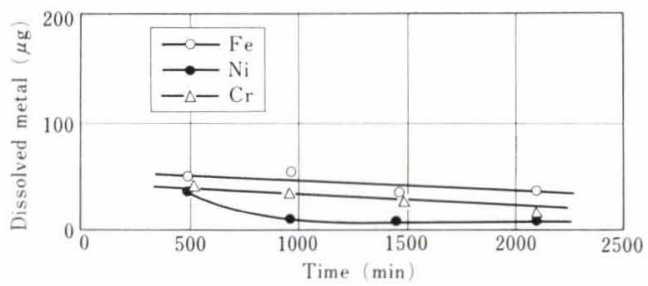

Fig. 11. Change in amount of dissolved metals with lapse of time in stress corrosion cracking of $20 \mathrm{Cr}-20 \mathrm{Ni}$ steel in $\mathrm{MgCl}_{2}$ boiling at $143^{\circ} \mathrm{C}$

Applied stress: $35 \mathrm{~kg} / \mathrm{mm}^{2}$

the dissolved $\mathrm{Fe}$ and $\mathrm{Ni}$ is about 3: 1 which is almost equal to the ratio of the alloy composition of $\mathrm{Fe}-20 \mathrm{Cr}$ $20 \mathrm{Ni}-\mathrm{P}$. The fracture times were $690 \mathrm{~min}$ under $25 \mathrm{~kg} / \mathrm{mm}^{2}, 310 \mathrm{~min}$ under $30 \mathrm{~kg} / \mathrm{mm}^{2}$ and $180 \mathrm{~min}$ under $35 \mathrm{~kg} / \mathrm{mm}^{2}$ respectively.

One noticeable result is that the amount of the dissolved metals is dependent on the crack densities of the fractured specimens as shown in Fig. 9.

The time dependence of the dissolution of metals during SCC is shown in Figs. 10 and 11. The amounts of dissolved $\mathrm{Fe}$ and $\mathrm{Ni}$ of the susceptible $\mathrm{Fe}-20 \mathrm{Cr}-$ $20 \mathrm{Ni}-0.076 \mathrm{P}$ alloy began to increase at about $180 \mathrm{~min}$ after SCC test had started and it increased rapidly at about $40 \mathrm{~min}$ before the fracture.

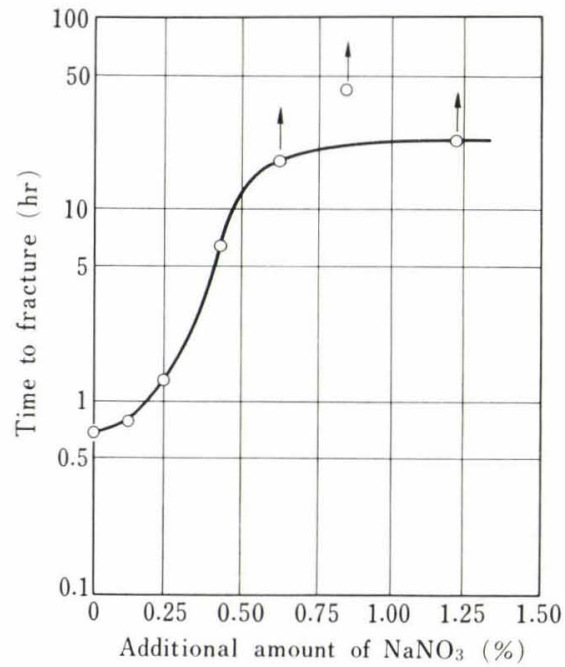

Fig. 12. Effect of additional amount of $\mathrm{NaNO}_{3}$ on time to fracture of 304 stainless steel in $\mathrm{MgCl}_{2}$ boiling at $143^{\circ} \mathrm{C}$

Applied stress: $\quad 30 \mathrm{~kg} / \mathrm{mm}^{2}$

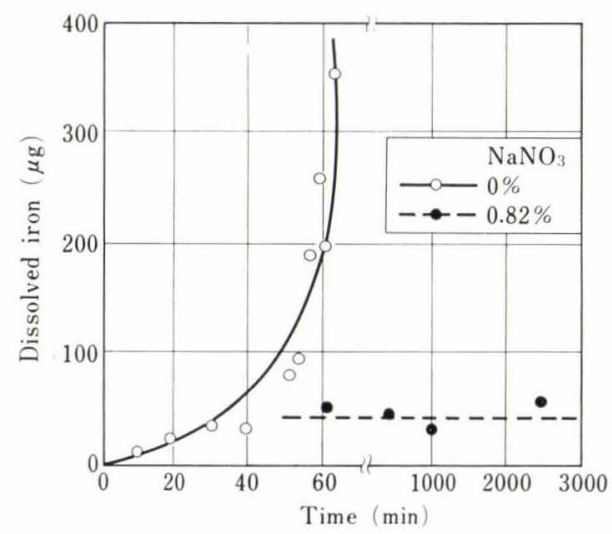

Fig. 13. Effect of $\mathrm{NaNO}_{3}$ addition on dissolved iron in 304 stainless steel in $\mathrm{MgCl}_{2}$ boiling at $143^{\circ} \mathrm{C}$ Applied stress: $30 \mathrm{~kg} / \mathrm{mm}^{2}$

On the other hand, as it is clearly shown in Fig. 11, the resistant alloy, $\mathrm{Fe}-20 \mathrm{Cr}-20 \mathrm{Ni}\left(\mathrm{T}_{f}\right.$ : more than $330 \mathrm{hr}$ ), showed no increase in the amounts of the dissolved metals.

As mentioned before, the $\mathrm{NaNO}_{3}$ addition to the boiling $\mathrm{MgCl}_{2}$ solution stopped the progression of the cracks and lead the couple current to zero. Figure 12 also indicates that the fracture time of Type 304 in the solution with $0.4 \% \mathrm{NaNO}_{3}$ is 10 times longer than that without $\mathrm{NaNO}_{3}$ and the fracture did not occur in solutions with more than $0.6 \% \mathrm{NaNO}_{3}$. As it is shown in Fig. 13, the dissolution of Fe during SCC did not increase in the solution containing sufficient amount of $\mathrm{NaNO}_{3}(0.82 \%)$. No cracks were observed at all on the specimen which was tested in the solution with sufficient amount of $\mathrm{NaNO}_{3}$.

\section{Relation between Dissolved Fe Content, Couple Current and Elongation}

The time dependence of the dissolution of $\mathrm{Fe}$, the couple current and the elongation of Type 304 during $\mathrm{SCC}$ is shown in Fig. 14. The rapid increase of the elongation coincides well with those of the dissolved 


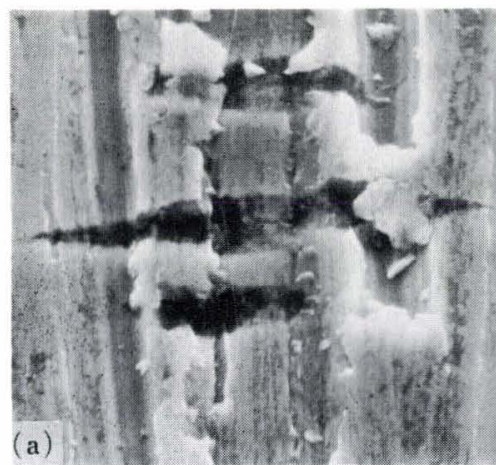

(a) $2 \min (\times 5000)$

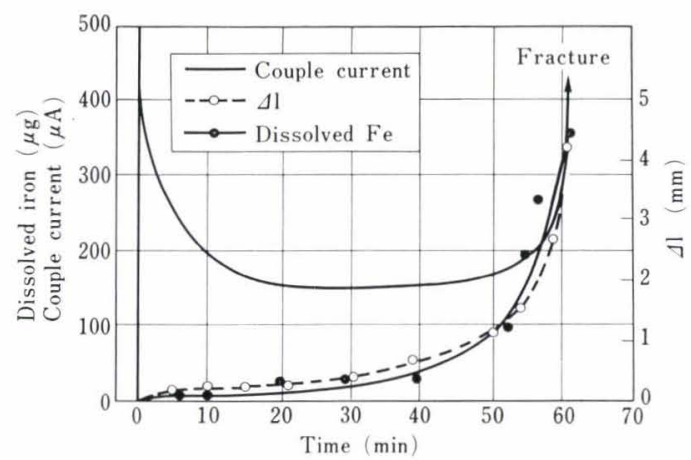

Fig. 14. Change in amounts of couple current, dissolved iron and $\Delta 1$ with lapse of time in stress corrosion cracking of 304 stainless steel in $\mathrm{MgCl}_{2}$ boiling at $143^{\circ} \mathrm{C}$

Applied stress: $\quad 30 \mathrm{~kg} / \mathrm{mm}^{2}, \Delta \mathrm{l}$ is the difference between initial length and elongated length

amount of $\mathrm{Fe}$ and the couple current. This result obviously indicates that the metal dissolution plays an important role in the crack propagation. One example of the initiation and the propagation processes of the cracks is shown in Photo. 1. The visible fine cracks were observed only 2 min after SCC test started and they grew in the direction almost perpendicular to the applied stress. Finally they formed open cracks and linked together to fracture.

Comparing the dissolved Fe content in Fig. 14 with the crack behavior in Photo. 1, it is understood that the metal dissolution was small while fine cracks grew. The metal dissolution extremely increased at the stage when the surface fine cracks developed to open cracks. The time of the rapid increase in the elongation and the couple current also coincides with the time of the formation of the open cracks.

\section{Initiation of Corrosion Grooves and Cracks}

As mentioned above, the propagation of cracks and the metal dissolution corresponded well to each other and the cracks were considered to propagate with the metal dissolution.

Photograph 2 shows the transmission electron micrograph of the initial cracks which were observed in the stress-corroded thin film of $\mathrm{Fe}-20 \mathrm{Cr}-20 \mathrm{Ni}-0.23 \mathrm{~N}$ alloy in the $\mathrm{MgCl}_{2}$ solution boiling at $143^{\circ} \mathrm{C}$. The corrosion trenches were clearly observed along the slip lines. These corrosion grooves seemed to grow up

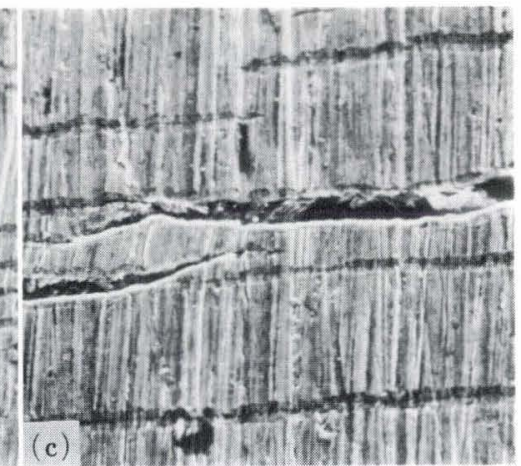

(c) $40 \mathrm{~min}(\times 50)$

(a) Nucleation of fine cracks (b) Growth of fine cracks (c) Formation of cracks

Photo. 1. The propagation of cracks in stress corrosion cracking of 304 stainless steel in $\mathrm{MgCl}_{2}$ solution boiling at $143^{\circ} \mathrm{C}$ under stress of $30 \mathrm{~kg} / \mathrm{mm}^{2}$

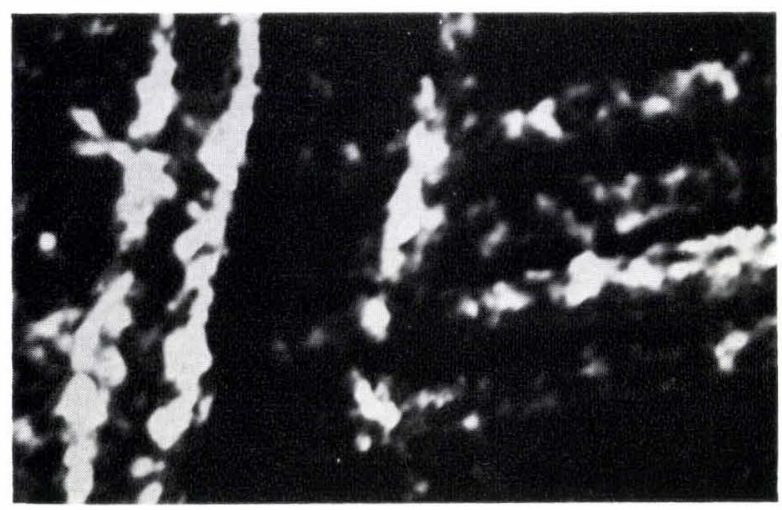

Photo. 2. Initiation of attack at slip lines on $20 \mathrm{Cr}-20 \mathrm{Ni}-0.23 \mathrm{~N}$ steel foil in $\mathrm{MgCl}_{2}$ solution boiling at $143^{\circ} \mathrm{C}$. Slip was made in $\mathrm{MgCl}_{2}$ solution by bending the foil for $2 \min (\times 20000)$

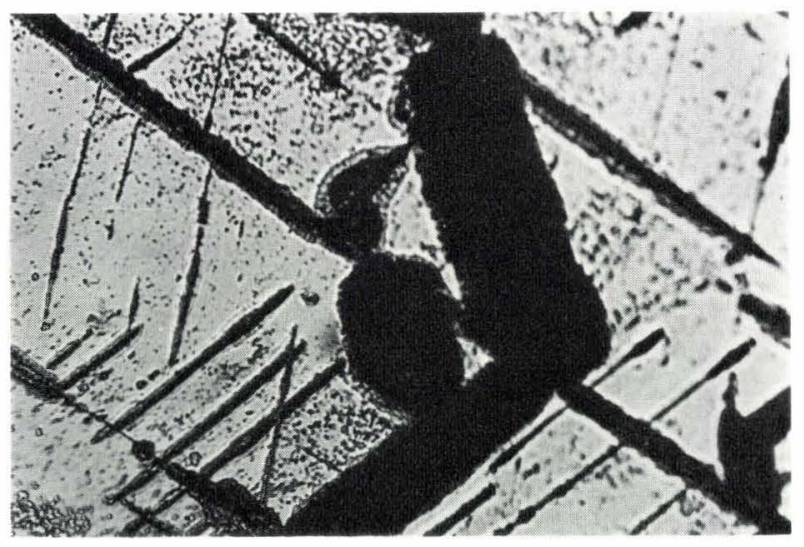

Photo. 3. Attack at slip lines on $20 \mathrm{Cr}-20 \mathrm{Ni}-0.23 \mathrm{~N}$ steel in $\mathrm{MgCl}_{2}$ solution boiling at $143^{\circ} \mathrm{C}$ under stress of $30 \mathrm{~kg} / \mathrm{mm}^{2}(\times 500)$

to the cracks as shown in Photo. 3. These cracks continued to grow in the direction almost perpendicular to the applied stress. Photograph 4 clearly demonstrates that the cracks of $\mathrm{Fe}-20 \mathrm{Cr}-20 \mathrm{Ni}-0.034 \mathrm{P}$ alloy propagated mostly in the direction normal to the applied stress and along the slip steps at the crack tips. From the above results, it can be concluded that the metal dissolution at the slip steps plays a very important role for the crack initiation and propagation. 


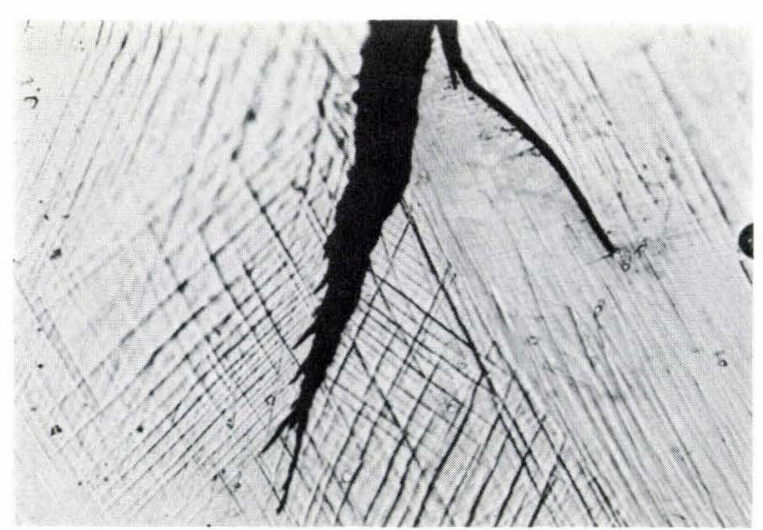

Photo. 4. Crack formed on 20Cr-20Ni-0.034P steel in $\mathrm{MgCl}_{2}$ solution boiling at $143^{\circ} \mathrm{C}$ under stress of $30 \mathrm{~kg} / \mathrm{mm}^{2}$. Note that crack propagates along slip lines at crack tips. $(\times 500)$

\section{Discussion}

The present experimental data clearly indicate that there is a very close correlation among the couple current, the metal dissolution and the crack propagation during SCC of austenitic stainless steels in the boiling $\mathrm{MgCl}_{2}$ solution.

The cracks were apparently observed to grow from the corrosion grooves along the slip lines as shown in Photos. 2 and 3. Moreover, it was recognized that either the addition of the oxidizer $\left(\mathrm{NaNO}_{3}\right)$ or the application of the cathodic current prevented further propagation of the open cracks as shown in Figs. 6 and 7. On the basis of the above results, the SCG mechanism of austenitic stainless steels is considered as follows.

(1) The anodic dissolution of $\mathrm{Fe}$ and $\mathrm{Ni}$ occurs at the fresh metal surface (slip step) which is exposed by the plastic deformation (the formation of the corrosion grooves).

(2) The growth of the corrosion grooves to the fine cracks by the continuous metal dissolution is accelerated by the plastic deformation at the bottom of the grooves.

(3) The growth of the fine cracks to the open cracks and the linkage of the cracks to the fracture are promoted by the additional plastic deformation accompanied with accelerated metal dissolution.

It is noted that the whole mechanism of the SCC of austenitic stainless steels in the boiling $\mathrm{MgCl}_{2}$ solution is mostly dominated by the anodic dissolution of metals along the slip steps. The rapid metal dissolution occurring along the slip steps is probably due to the break of the passive film by the plastic deformation. The initial large couple current observed in Figs. 4 to 6 is considered to be caused by the metal dissolution at the freshly exposed metal surface. The couple current decreased very sharply to a certain value depending on the susceptibility to SCC of materials and the non-susceptible alloys showed almost zero couple current by the complete repassivation of the freshly exposed surface. These results clearly suggest that the protectivity of the repassivated film to the chloride ions plays the definite role in the SCG resistance of the steels. Although it is not known whether the repassivated film is the usual passive film or the deposited film, it is considered to be a kind of the passive film from the fact that the specimens become immune to SCC with the addition of the passivator like $\mathrm{NaNO}_{3}$.

It has been reported ${ }^{9,11,13)}$ that the main cathodic reaction in the SCC of austenitic stainless steels in the boiling $\mathrm{MgCl}_{2}$ solution is the hydrogen reduction. Since a large amounts of hydrogen bubbles were observed to come out from inside of the open cracks in this study, the cathodic reaction was possible to be the hydrogen reduction reaction. This phenomenon of hydrogen evolution suggests that the cathode area exists adjacent to the active local anodes at the crack tips.

Total amount of the dissolved metals calculated from the coulombs given by the couple current was 100 to $300 \mu \mathrm{g}$ in Type 304 stainless steel and it was a little less than the analyzed value. This result can also be explained from the idea that a part of the anodic current was consumed by the cathodic reaction occurring near the crack tips in the stressed specimen.

Although the fact that hydrogen gas was evolved from inside of the cracks was favourable to the idea of the hydrogen mechanism of SCC of austenitic stainless steels, the fact that the cathodic polarization stopped the crack propagation (Fig. 7) made the hydrogen mechanism less probable.

In this study, only $\mathrm{Fe}$ and $\mathrm{Ni}$ of the stainless steel components were observed to dissolve into the solution by the same ratio with the alloy composition. Analyzing the test solution, Wilde ${ }^{16)}$ also reported that only $\mathrm{Fe}$ and $\mathrm{Ni}$ dissolved at the corrosion potential. On the other hand, Reed and Paxton ${ }^{17}$ ) found that only $\mathrm{Ni}$ dissolved into the solution. By measuring the change of the corrosion potentials, Hoar and Hines $^{13)}$ and Barnartt and VanRooyen ${ }^{12)}$ suggested that $\mathrm{Fe}$ and $\mathrm{Cr}$ dissolved into the solution and the Nirich surface was remained. Nielsen ${ }^{18}$ ) showed that Cr was rich in the corrosion product formed on the SCG fracture surface by the analysis with the electron and X-ray diffraction methods. Using X-ray diffraction method, Pickering, et al. ${ }^{19)}$ also reported that the corrosion product consisted of $\mathrm{Fe}$ and $\mathrm{Cr}$ oxides and that $\mathrm{Ni}$ was not observed in the corrosion product.

From the present results and the previous works, it is reasonable to consider that $\mathrm{Cr}$ deposited as the $\mathrm{Cr}$ oxide immediately after dissolution rather than to consider that Cr did not dissolve at all.

\section{Conclusions}

The SCC mechanism of austenitic stainless steels was investigated by the measurements of the couple current, the elongation, and the amount of dissolved metals. The following results were obtained.

(1) The couple current was observed when the applied stress was large enough for the plastic deformation. The current was associated with the anodic metal dissolution which promoted the crack propagation. 
(2) The dissolved metals during the SCC were mainly $\mathrm{Fe}$ and $\mathrm{Ni}$ and the $\mathrm{Cr}$ content in the solution was negligibly small.

(3) The non-susceptible alloys did not show any measurable couple current, elongation, and metal dissolution.

(4) The cracks were initiated at the freshly exposed metal surface caused by the slip.

(5) The crack propagation was completely stopped either by the cathodic polarization or by the $\mathrm{NaNO}_{3}$ addition to the solution.

From the above results, it is concluded that the SCC is initiated by the anodic dissolution at the fresh metal surface exposed by the slip and that the cracks continue to propagate by further preferential metal dissolution caused by the localized plastic deformation at the bottom of the corrosion grooves.

\section{Acknowledgements}

The authors would like to thank Dr. T. Ohtake, former Director and Dr. S. Nagashima, Director for their advice and permission to publish this work.

\section{REFERENCES}

1) T. P. Hoar and J. C. Scully: J. Electrochem. Soc., 3 (1964), 348.

2) R. W. Staehle, T. J. Royecela, T. L. Raredon, E. Serrate, C. R. Morin and R. V. Farrar: Corrosion, 26 (1970), 451.
3) P. R. Swann: Corrosion, 19 (1963), 102

4) K. C. Thomas, R. Stickler and R.J. Allio: Corr. Sci., 5 (1965), 71 .

5) N. Takano and S. Shimodaira: Trans. JIM, 7 (1966), 193.

6) T.J. Smith and R. W. Stachle: Corrosion, 23 (1967), 117.

7) D. A. Vermilyea: Proceedings of Conference, Fundamental Aspects of Stress Corrosion Cracking, NACE, (1969), 15 .

8) D. A. Vaughan, D. I. Phalen, C. L. Peterson and W.K. Boyd: Corrosion, 19 (1963), 315 t.

9) P. R. Rhodes: Corrosion, 25 (1969), 462.

10) H. H. Uhlig and E. W. Cook, Jr.: J. Electrochem. Soc., 116 (1969), 173

11) D. A. Vaughan and D. I. Phalen: ASM, 5 (1965), 39

12) S. Barnartt and D. VanRooyen: J. Electrochem. Soc., 108 (1961), 222

13) T. P. Hoar and J. G. Hines: Int. Comit. for Electrochem. Thermody \& Kinetics, (C.I.T.C.E.), 8 (1958), 273.

14) M. B. Whiteman and A. R. Troiano: Corrosion, 21 (1965), 53.

15) B. E. Wilde: J. Electrochem. Soc., 118, (1971), 1717.

16) R. Tanaka, K. Nagasaki and T. Hsu: Tetsu-to-Hagané, 55 (1969), 576

17) R. E. Reed and H. W. Paxton: 1st Int. Congr. Met. Corr., Butterworths, London, (1962), 301.

18) N. A. Nielsen: Phys. Metal. Stress Corr. Fract., T. N. Rhodin, ed., Interscience, New York, (1959), 121.

19) H. W. Pickering, F. H. Beck and M. G. Fontana: Corrosion, 18 (1962), $230 \mathrm{t}$ 